\title{
Reconceptualizing dominant discourses in early childhood education: Exploring 'readiness as an active-ethical-relation
}

\author{
KATHERINE EVANS \\ University of Exeter (United Kingdom)
}

This paper considers the landscape of early childhood education in England to be dominated by discourses of 'readiness-for-school' and 'readiness-for-learning' that act to heavily stratify the educational spaces inhabited by young children. The 'ready-child' is constructed as a normative identity towards which the 'unready' child is expected to progress. This is not to imply that 'readiness'/'unreadiness' is constructed as a binary relationship, but rather that 'readiness' is predominantly understood as a predefined spectrum of knowledge, skills and identities. This paper considers the confinement of children within such predetermined subject positions to be problematic, as inevitably not all children will achieve these normative ideals or progress across this spectrum in a recognizable manner, resulting in their exclusion from positions of 'success'. In response to these concerns, this article seeks to disrupt dominant conceptualizations of 'readiness' in the context of early childhood education, expanding space for alternative ideas, theories and practices. In a deliberate move away from concepts that relate 'readiness' to predefined goals, outcomes and identities, the possibility of thinking with a complex logic in order to generate new ideas, understandings and practices is explored. Approaching complexity from the 'outside-in', this paper draws in particular on the concept of 'becoming' (Deleuze \& Guattari, 1987), exploring 'readiness' as a complex process of emergence, always open to the unpredictable and the new. It is argued that 'readiness' is part of an open-ended 'becoming', rather than a pre-defined 'state' of being. Drawing on the work of Deleuze (1983), Deleuze and Guattari (1987) and Dewey (1899/2010; 1916), this reconceptualized idea of 'readiness' does not hark back to romantic notions that might consider all forms of development equally valid or desirable. This paper argues instead that it matters greatly what and how children 'become' and as such, 'readiness' for these emergent 'becomings' must be considered an ethical and political endeavor. 


\section{Introduction}

This paper explores the concept of 'readiness' in the context of early childhood education. The discussion developed here is emergent from a wider piece of doctoral work, funded by the Economic and Social Research Council in England, that focuses on challenging dominant discourses of 'readiness' in early childhood education. The theoretical discussion is punctuated with a series of interludes: stories and reflections from practice. Some draw on my own experience as an early childhood teacher, some are the stories of children and adults I have encountered through my $\mathrm{PhD}$ research. All have contributed to the ideas developed in this paper and in this sense are considered 'data' in this reconceptualization of 'readiness'.

This paper argues that dominant conceptions of 'readiness', as articulated within the educational discourses of state politics, are expressed largely as transcendent norms ${ }^{1}$, according to which the child is considered 'ready' (for school, for 'more formal' learning etc.) in relation to a specific form or function, defined in advance and as a universal identity. Within the context of the Early Years Foundation Stage (EYFS) (Department for Education (DfE), 2012), the policy framework for early childhood education and care in England, 'readiness' is officially defined in relation to a specific series of fixed goals and outcomes that form a summative assessment of each child's 'level' of learning and development at the transition between early childhood and compulsory school education. Assessment against these goals is statutory and the outcomes are considered to provide a "well rounded picture of a child's knowledge, understanding and abilities, their progress against expected levels, and their readiness for year 1" (DfE, 2012, p.11). The content of these 17 Early Learning Goals (DfE, 2012; DfE, 2013) acts to predefine the knowledge, capabilities and by extension the experiences that are educationally 'worthwhile' for children in their early years. In a manner similar to that identified by Dewey (1899/2010), "almost the only measure for success is a competitive one" (p.9) in which the child is judged against a particular standard. This paper considers the identification of fixed and static aims as a standard measure of 'readiness' to be problematic. As Dewey (1916) identifies, where only a single, static aim has been thought of, the only course of movement is ahead towards that mark, defining a narrow course in which actions have limited meaning, and failure to meet that aim is attributed to the perverseness of conditions or the inadequacy of the individual in comparison to the desired aim. MacNaughton (2005) hi-lights the problematic nature of such aims in the context of early childhood education, expressing concern that through the development and reification of particular 'truth statements' about children's learning and development, positioned as static outcomes, it has been considered possible to identify delay, deficit and abnormal development. Reference to such 'truth statements'

${ }^{1}$ This paper interprets Deleuze and Guattari's use of the term 'transcendence' as the existence of external, or 'higher-level' principles assumed to establish a static point of reference against which relations can be measured and judged. It is recognized, however, that this is just one interpretation of the notion of transcendence. 
can therefore position children on a predefined spectrum of 'un/readiness', a positioning that can affect their educational experiences from the very earliest days.

\section{Interlude: 'Readiness for school'}

Working as an early childhood teacher, this positioning of children in relation to notions of 'readiness' was clearly evident. In particular, children's 'readiness-for-school' was a dominant influence on practice, pedagogy and on the expectations placed on my professional work by the local education authority and by national policy frameworks and statutory guidance. One of my key tasks as a teacher was to produce 'data' throughout the academic year, recording children's level of learning and development in relation to specific knowledge, skills and capabilities. This data had a number of functions, including as a tool for practitioners to consider provision and to reflect critically on the nursery environment. During the final term of each academic year however, this data had a specific function, to measure, record and communicate children's 'readiness' to cope with the demands of compulsory schooling. Discussions at this transition time would be dominated by children's correspondence with the goals and outcomes that were predefined within policy frameworks and considered to represent their 'readiness' for school and for an increasingly formal pedagogical experience. I would regularly be asked to indicate whether I considered children to be of 'high', 'middle' or 'lower' ability, information considered necessary in planning the school environment and to support their transition from nursery. In addition to this level of 'ability', information commonly sought prior to children's transition to school was whether they were able to sit still and attend to an adult directed activity, whether they understood rules and boundaries, and whether they could form positive relationships with their peers. Whilst I could see how this information could be useful, it would frustrate me that the 'readiness' of schools and children was considered in such narrow terms. 'Readiness' was thought about only in relation to predefined ways of being and an already established idea of school culture. For many children I worked with, this culture was unfamiliar (see Evans, 2013). These children, therefore, entered school in a deficit position, with their early school days committed to 'catching-up' with peers whose cultural experience predisposed them to be successful in this environment.

Based on such experiences, this paper contends that conventional understandings of 'readiness' rely on a mechanistically linear logic, constructing it as a normative and standardized goal. This kind of logic is considered to reduce complexity in relation to understandings and practices of 'readiness', restricting recognizable development to that which is seen to input directly into a normative standard. In order to challenge this normative conception, this paper considers it necessary to engage with a complex logic, one that is capable of thinking about the unpredictable and non-linear elements of children's learning in creative and productive terms. A complex logic is particularly helpful as it "makes it possible to see the non-linear, unpredictable and generative character of educational processes and practices in a positive light, focusing on the emergence of meaning, knowledge and understanding" (Osberg \& Biesta, 2010, p. 2). The approach of this paper is to explore a complex understanding of 'readiness' "from the outside-in" (Osberg \& Blesta, 2010, p. 3), through a theoretical framing emergent from the work of Deleuze (1983; 1988a; 1988b) and Deleuze and Guattari (1987), in 
particular the concepts of 'becoming', 'multiplicity' and the 'Body without Organs'. Inspired by the scholarship of Semetsky (2003; 2006), this discussion engages these Deleuzian ideas, in an educational context, with the philosophical thought of Dewey (1899/2010; 1916). Through engagement with these concepts and with the kind of creative and unpredictable thought made possible by a complex epistemological approach, this paper seeks to produce a radically new conception of 'readiness' in the context of early childhood education, one that emerges as an 'active-ethical-relation' with the potential to open up, rather than close down complexity.

\section{'Readiness' and the 'space' of early childhood education}

Lorraine (2005) suggests that normative subjectivity tends to emphasize states of equilibrium, assimilating space and time to socially recognizable, fixed coordinates, with respect to which all movement can be mapped. Deleuze and Guattari (1987) describe this space as a 'plane of organization', productive only of static and self-contained subjects who develop as a form of mimesis, "a chain of beings perpetually imitating one another progressively and regressively" (p. 235). This 'plane of organization' is characterized by what Deleuze and Guattari (1987) have called stratification, in which "(f)orms and subjects, organs and functions are strata, or relations between strata" (p. 269). Bodies within this organized space are identifiable as centralized and hierarchical organisms that appropriate the matter-energy of the organs and funnel a surplus portion of them to the benefit of transcendence, conceptualized as a superior body or stratum (Protevi, 2000). The 'plane of organization' therefore acts to create the individualized subject as a more-or-less imperfect representation of a series of pre-given norms, as evidenced in the construction of specific Early Learning Goals within the policy framework for early childhood education in England (DfE, 2012). The 'ready-child' is constructed through these norms as a majoritarian identity category, which Cunniff Gilson (2011) suggests is a category defined in virtue of its dominance and the ways in which it sets particular standards in relation to hierarchical terms of identity. She identifies how major identity categories distribute and maintain binary relations that reinforce their dominance, stabilizing standardized and normative patterns of development. Whilst it is not the intention of this paper to construct 'readiness'/'unreadiness' as a binary, it is argued that policy technologies, such as Early Learning Goals (DfE, 2012) or Early Years Outcomes (DfE, 2013), create a normative spectrum on which it is assumed that each individual child can be positioned in terms of their relative 'readiness' for school or for a particular form of learning.

It is argued, therefore, that the construction of the 'ready-child' as a majoritarian identity category acts to normalize particular developmental trajectories, positioning particular identities and ways of being on a spectrum organized according to a hierarchy of 'unreadiness'/'readiness'. This paper argues that the concepts of 'readiness' which dominate within political discourses surrounding early childhood education act to organize this spectrum of 'unreadiness' to 'readiness', predefining desirable subject positions and trajectories of development, thus systematically reducing complexity in 
relation to the ways in which early learning and development is understood and experienced. This relation of 'readiness' to pre-determined goals and outcomes is understood as a laying out and defining of territories, substituting open and dynamic space, which Deleuze and Guattari (1987) describe as the 'plane of composition'², for the increasingly rigid segmentarity of the 'plane of organization' (Cunniff Gilson, 2011). These territories, demarcated by the pre-determined outcomes of early childhood education policy, become static markers of identity, rigidly defining 'readiness' according to a particular spectrum of characteristics, observable in the individual child, a process through which individualized segments "seem to lose their ability to bud" (Cunniff Gilson, 2011, p. 212) and to produce creative and unexpected deviations from the norm.

\section{An alternative discourse of 'readiness'}

In itself, identifying dominant constructions of 'readiness' as potentially damaging has limited potential to change these dominant perceptions. In order to affect change in the landscape of early childhood education it is necessary to go beyond critique to suggest alternative concepts. This paper asks, therefore, if dominant discourses of 'readiness' are a problem, what is the alternative? How can we think, talk and live 'readiness' without reference to the predetermined, normative standards, fixed goals and outcomes that make it a majoritarian, identity driven term and construct it as a potentially exclusionary concept?

One way to explore this question is to think with the concept of 'becoming'. For Deleuze and Guattari (1987), 'becoming' offers a way of conceptualizing progress and change that does not rely on ideas of 'series' and 'structure' that tend toward higher, transcendent terms. A Deleuzo-Guattarian 'becoming' is not resemblance, imitation or identification, nor is it progression or regression along a defined series or chain of beings perpetually imitating one another. 'Becoming' is creative production, concerned primarily with the production of difference. Semetsky (2011) develops this point, highlighting that rather than classical theoretical questions of being, the focus of Deleuzian philosophy is the very praxis of 'becoming-other'. This 'becoming-other' is actualized when a degree or intensity enters into composition with other degrees or other intensities, to form another, as part of the multiplicity that constitutes the 'plane of composition' (Deleuze \& Guattari, 1987). The movement of 'becoming' does not deal in the development of forms, but emerges through movement, through speed and slowness between modules and particles of all kinds, human and non-human, natural and artificial. Deleuze and Guattari (1987) talk of 'becoming' as an 'involutionary' process, inherently creative and affirmative of the vitality of life and of difference (Parr, 2010). As Parr (2010) states, "[a]ccording to this schema creative transformation is immanent, taking place on a plane of consistency that precedes univocal Being" (p. 60). As an immanent proliferation, the line of 'becoming' that emerges through processes of involution, whilst directional, has

2 In A Thousand Plateaus, Deleuze and Guattari also use the term 'plane of consistency', which is reflected in some of the citations throughout this paper. 
no fixed beginning or end point, passing only in the middle as a form of emergence. This contrasts sharply with the 'plane of organization', which is composed only of contiguous points and lines drawn between pre-defined origins and destinations.

Understanding conventional spaces of early childhood education in terms of a 'plane of organization' constructs the identity of the child as a tracing of pre-plotted points. 'Readiness' becomes defined in relation to each child's 'accurate' tracing of these points with the normative subject of early childhood education being sustained through interactions and experiences that produce evolutionary movements towards a fixed identity. In contrast, a line of 'becoming' is not defined by the connection of pre-plotted points or pre-mapped territories. The line of 'becoming' emerges, comes up through the middle, running perpendicular to points as first perceived and transversally to its localizable relation to other, predefined and distant points (Deleuze \& Guattari, 1987). The line of 'becoming' is therefore unpredictable, impossible to plan in advance and infinite, in that it does not extend towards a planned telos, from which the identity of the 'ready-child' can be derived.

\section{Becoming and multiplicity}

This notion of 'becoming' negates the existence of a stable series of identities, constructed as a spectrum against which the progressive development of 'readiness' can be related. Focus is shifted away from a "stable, rational individual, experiencing changes but remaining, principally, the same person" (Stagoll, 2010, p. 22), towards a 'self' "conceived as a constantly changing assemblage of forces" (ibid). In this sense, the 'self' does not exist in isolation, but as part of a multiplicity, 'becoming' through its connections and propagations. This conception of 'becoming' "conceives of a body (be it physical or conceptual) as a set of habitually patterned forces that sustains itself through its power to affect and be affected by forces surrounding it" (Lorraine, 2005, p.160).

Understanding the space of early childhood education as a multiplicity is important in shifting conceptions of 'readiness'. Deleuze (1988a), distinguishes between two different types of multiplicity. One he identifies as "a multiplicity of exteriority" (p. 38), based on "quantitative differentiation" and "difference in degree" (ibid). This is a "numerical multiplicity" (p. 38) within which 'objects' divide only by differences in degree, remaining ultimately the same, each object being "characterized by the perfect equivalence of the divided and the divisions, of number and unit" (Deleuze, 1988a, p. 41). Within a numerical multiplicity, it is possible to construct the 'ready-child' as an object, produced from a quantitative accumulation of parts (environmental experiences, innate developmental milestones etc.), which by degree combine to form the complete object. What matters in relation to children's learning, according to the logic of this quantitative multiplicity, is the progressive actualization of the object-state, which can also be used as a point against which children's 'readiness' can be measured and interpreted, thus positioning them on a spectrum of 'unreadiness' to 'readiness'. Within such a multiplicity complexity is reduced, for difference and change can only proceed by 
degree. The object may change by addition or subtraction, but ultimately does not change in kind, remaining principally the same, just at a greater or lesser state of completion (or a greater or lesser state of 'readiness'). In a manner similar to the type of 'weak emergence' described by Biesta (2010), development and progression, leading towards a state of 'readiness', can be explained and predicted according to a cause and effect model in which 'readiness' can be conceived as a stable output, equitable to a particular input.

In contrast, Deleuze (1988a) describes a qualitative, or continuous multiplicity, which emerges not by difference in degree but by difference in kind. Fundamentally, this nonnumeric multiplicity cannot be divided without changing in nature. The introduction of something new into the multiplicity affects a change, the eruption of a line of flight ${ }^{3}$ or the emergence of something unique and unpredictable. In complexity terms, this may be understood as a form of 'strong emergence', in which the emergent properties of a system cannot be deduced, even in principle, in terms of the earlier state of the system (Biesta, 2010). There is, therefore, no particular essence that can underpin a qualitative multiplicity, just as there is no ultimate telos or final object that marks its successful completion.

\section{Interlude: 'Readiness' and risk taking}

The danger of focusing on 'readiness' as a predefined end point and set of characteristics to be acquired was highlighted during my PhD research. During my first year of fieldwork I had worked closely with one teacher and her reception class of 4 and 5 year old children ${ }^{4}$. The following academic year this teacher began to teach a mixed class of year 1 and year 2 children, many of whom she had taught previously during their first year of school. We discussed her current perceptions of these children as learners. She had been struck, in the early weeks of the school year, that many of the older children, now in year 2, and having spent a year engaging with the Key Stage 1 curriculum, were finding it challenging to engage in activities that were not planned and directed by adults. She had observed children who were confident and capable within the activities she led as class teacher, struggle when exposed to open ended resources such as Lego,

${ }^{3}$ Deleuze and Guattari employ the concept of the 'line of flight' throughout $A$ Thousand Plateaus, emphasizing the importance of "movements of deterritorialization and destratification" (1987, p. 3). Lorraine (2010) describes their use of the term thus: "A 'line of flight' is a path of mutation precipitated through the actualization of connections among bodies that were previously only implicit (or 'virtual') that releases new powers in the capacities of those bodies to act and respond." (p. 147).

${ }^{4}$ Within mainstream education in England, the 'reception class' is typically the first year of children's compulsory schooling. Children will normally enter their reception year at four years old and will turn five during the academic year. The reception year is the final year of the Early Years Foundation Stage (DfE, 2012), after which children progress into the Key Stage 1 curriculum, which encompasses years one (age five to six) and two (age six to seven) of primary school. The Department for Education (DfE, 2012) considers that the shift between the EYFS and Key Stage 1 should involve a gradual shift towards more activities that are led by adults, with fewer opportunities for children to engage in self initiated activities. 
building blocks or play-dough. Contexts in which these children were expected to follow their own lines of enquiry, to ask their own questions and to experiment with the unknown appeared to pose a significant challenge. She was surprised by this, as many of these children had been working confidently in this kind of open ended and self-initiated manner when she had taught them in reception, when self-initiated activities had been a common part of their school experience. Reflecting on this observation in relation to the notion of 'readiness', we explored the idea that whilst many of these children were considered 'ready' for the demands of the curriculum: they were able to follow instructions, listen carefully and make use of their developing reading and writing skills, they were not 'ready' to take the risks within their learning that following their own enquiries might bring. In contexts where learning might be unpredictable, in which they were expected to follow their own enquiries without the structure of adult guidance or direction, these children appeared to lack confidence. We considered the possibility that the more formal and adult directed pedagogical approach of the curriculum they had been engaged with during the past year may have influenced their 'readiness' to take these risks. We questioned whether working towards a goal of 'readiness' as the outcome of an accumulation of specific knowledge, skills and characteristics may have impoverished these children's ability to engage in open-ended and creative learning. It is possible that the organization and structure of their school experience may have acted to close down and limit their 'readiness' to follow their own lines of enquiry without the 'safety' of a predictable structure or outcome.

As continuous and qualitative multiplicities, understood in terms of 'strong emergence', the spaces that young children pass through in their early childhood experience must allow for the possibility of constructing open-ended lines of flight (Deleuze \& Guattari, 1987) that extend within and beyond the multiplicity, constructing the space through the development of ongoing connections and relationships. As qualitative multiplicities, early childhood spaces are defined only by abstract lines, through which they continually change their nature and connect with other multiplicities (ibid). The abstract line enacts a particular type of unpredictable movement, making it impossible to know in advance the affects it will have or the connections it will make. As "no one can say where the line of flight will pass" (Deleuze \& Guattari, 1987, p. 250) it is impossible to predict the trajectory that 'becoming' will take, or to impose upon it a fixed end point. Within a multiplicity, 'readiness' should not be understood in relation to the achievement of a fixed identity, but rather as the conditions necessary for open-ended 'becoming' to happen. This concept considers 'readiness' to be a productive relation between different elements of a milieu or multiplicity, an active concept that produces, rather than measures, learning and development, prompting the creation of new and different knowledge and experience, rather than a continual representation of habitual patterns of the same.

\section{Creative transformation or haphazard movement?}

Conceptualizing learning, development and progression through the concepts of 'becoming' and 'multiplicity' has the potential to radically shift understandings of 'readiness' in the context of early childhood education, replacing the measurement of fixed goals and outcomes with attention to immanent and dynamic movement, the production of change and creative transformation. 
Considering, however, that 'multiplicity' and 'becoming' reject the finalization and unification of substance and form as fixed teloi (Protevi, 2000), it is important to ask what is it that 'becoming' is? It would be a misconception to assume that 'becoming' is aimless in its movement. In his discussion of education as preparation, Dewey (1916) explores a similar concept, stating, "[i]t is not a question of whether education should prepare for the future. If education is growth, it must progressively realize present possibilities, and thus make individuals better fitted to cope with later requirements" (p. 65). The difficulty that arises however, is that whilst 'becoming' as a form of growth does, necessarily, progress, it does not progress towards a fixed point, prompting the question that if this movement has no unified telos, what is it that these lines of flight are 'becoming' (Deleuze \& Guattari, 1987)? How is 'becoming' any different from a haphazard or aimless collection of individual movements, each following a selfinterested path to a self-actualized subject?

One way in which Deleuze and Guattari (1987) address this issue is through the concept of 'becoming-minoritarian'. This concept challenges conventional understandings of 'becoming', valuing instead movements that deviate from dominant minority or majority subject positions. Crucially, 'becoming-minoritarian' must not be confused with a minority subject position as an aggregate state, and equally, care must be taken not to automatically conceptualize identified minorities as de facto 'becomings'. As Deleuze and Guattari (1987) state, "Jews, Gypsies, etc., may constitute minorities under certain conditions, but that in itself does not make them becomings" (p. 291). Similarly, the 'child' may be considered a minority subject position (in relation to the non-child), however this does not automatically position them in a process of 'becoming'. Minority populations may be capable of serving as an active medium 'becoming', but only under conditions in which they cease to be a definable aggregate in relation to a defined majority (Deleuze \& Guattari, 1987). Zukauskaite (2011) indicates that 'becoming-minoritarian' should be understood as a deliberate line of escape from a minority position, and is therefore a properly political act. She states, "becomingminoritarian is not a 'natural' state or condition but a political affair" (p. 193). Similarly, Dewey (1899/2010) considers that in the context of the school, the moment children act they make a break with defined norms, individualizing themselves and ceasing to be part of a "mechanical massing of children" (p. 16), or in Deleuzian terms, they make a break with the predefined, majoritarian organization of the organism.

\section{Interlude: 'Carpet time'}

'Carpet time' formed a regular part of the children's Reception class experience. It was a time in which the whole class would come together and engage in activities led by an adult, most often the class teacher. Each child had an assigned 'carpet space' in which they were expected to sit, organized in order to promote the most productive class dynamic in terms of the children's ability to maintain attention and focus. The mass of children gathered in this space formed a kind of organism, structured in a specific way in order to produce a particular form of space, conducive to a particular form of learning. If all bodies in the organism maintained this structure, the desired 
form of space continued without disruption. Children received praise for displaying appropriate behaviors, such as sitting in their carpet space, sitting still and answering questions. Children would even reprimand each other if they strayed from their assigned spaces. Early on in the school year, the ability of individuals to maintain the positive dynamic of this massed organism was considered to be a sign of children's 'readiness' for the classroom environment. Behaviors that might disrupt the positive maintenance of this whole class context, such as lying instead of sitting in the carpet space or fidgeting rather than sitting still, were an indication that children had yet to learn the classroom culture, and support was structured in order to develop their 'readiness' to participate. To break with the structure of the organism was therefore discouraged in the whole class context and a sign that children might not yet be 'ready' for the demands of the school environment. Attempts to differentiate themselves from the group were discouraged and quickly redirected back to the expected norm.

Crucially, Cunniff Gilson (2011) considers that 'becoming-minoritarian' is not a revaluation of the degraded side of a majority/minority binary, but is instead a break from the rigidity of these dualist terms all together. Breaking with the rigidity of these binary segments opens up space for dynamic 'becomings-other', established via an affirmation of difference, diversity and multiplicity, and leading toward the creation of the new (Semetsky, 2011). The movement of 'becoming', and in particular 'becomingminoritarian', can never be understood as progress towards a series of fixed outcomes denoting 'readiness' for the 'next phase', a belief that resonates with Dewian philosophy and its theorizing of 'aims' in education. Dewey (1916) claims that if education is to have aims at all, they must be emergent from present conditions, being "based upon a consideration of what is already going on; upon the resources and difficulties of the situation" (p. 121). He considers that educational and moral theories which assume ends issuing from an external source act to "limit intelligence because, given ready made, they must be imposed by some authority external to intelligence, leaving to the latter nothing but a mechanical choice of means" (Dewey, 1916, p. 122). In contrast, 'becoming' extends the possibility of education occurring in the open and dynamic space of the 'plane of consistency', which is itself constantly unfolding, producing 'readiness' for a future that is as yet undefined.

\section{Becoming-minoritarian and the Body without Organs}

Deleuze and Guattari (1987) discuss the process of 'becoming' in relation to the concept of the 'Body without Organs' (BwO). Protevi (2000) describes the $\mathrm{BwO}$ as a 'destratified body', stating that, as an object or practice of construction the $\mathrm{BwO}$ is not reached by regression, for it is not the infantile body of our past, but the virtual realm of potentials for any number of potential bodily organizations that may be precluded by organismic organization. The BwO can be understood as the unknown potential of 'becoming', as that which remains once we have broken with the dominant patterns of the subjectified self. Deleuze and Guattari (1987) state, 
the $\mathrm{BwO}$ is not at all the opposite of the organs. The organs are not its enemies. The enemy is the organism. The $\mathrm{BwO}$ is not opposed to the organs but to that organization of the organs called the organism. (p. 158)

The organism, in this context, is understood as a stratum on the $\mathrm{BwO}$ that enacts a top down pressure, organizing the organs in a specific and static manner. As Deleuze and Guattari state, it is,

a phenomenon of accumulation, coagulation, and sedimentation that, in order to extract useful labor from the $\mathrm{BwO}$, imposes upon it forms, functions, bonds, dominant and hierarchized organizations, organized transcendencies. (1987, p. 159)

In the context of early childhood education, the organism can be understood as a function of the state apparatus that codes and regulates movements and flows, establishing rigid categories of form and function by which individual bodies ${ }^{5}$ can be understood. Coded and regulated by particular beliefs, habits, practices and policies, the top-down organization of early childhood spaces aims at developing particular forms and functions, including the child who is 'ready' at a particular point in space and time, themselves organized in relation to particular social and developmental norms as points of reference. In Dewian terms, this fixed and normative standard is codified in relation to adulthood as a terminal identity against which children and childhood can be comparatively judged (Dewey, 1916). The child-body is therefore organized in relation to the adult-body and as such a tendency is established "to take immaturity as mere lack and growth as something which fills up the gaps between the immature and the mature" (Dewey, 1916, p. 49). The child's growth and development is organized with a fixed end point in view, a majoritarian identity position that "fixes attention on what the child has not, and will not have until he becomes a man" (Dewey, 1916, p. 50). This form of organization enables learning and development to be broken up into discrete stages and sequences, structured according to fixed standards, potentially limiting understandings of 'readiness' to the achievement of a particular identity position, the successful attainment of which provides the foundation for the next, pre-defined, phase of learning and development.

Conceptualizing the $\mathrm{BwO}$ as a productive 'becoming' can be seen as a positive affirmation of complexity and as a commitment to maximizing the virtual, and therefore unknown potentials that may emerge within and between bodies as part of a multiplicity. In an educational context, this shifts attention from the achievement of subjectified identity positions (i.e., the 'ready-child') as fixed markers of progress and success, towards notions of the self as a threshold or door, a temporary 'phase space', a 'becoming' between two multiplicities (Deleuze \& Guattari, 1987). Massumi (1992)

${ }^{5}$ It is important to remember that for Deleuze and Guattari, the 'body' refers to any assemblage of parts standing in some relation to each other, with no distinction made between the natural and the artificial in this context. As such, a 'body' is defined not by simple materiality, but by relations of speed and slowness, motion and rest, and by its actions and reactions with respect to its environment or milieu (Baugh, 2010). 
expresses this concept through a vocabulary that resonates with a complex perspective. He states,

Think of the body without organs as the body outside of any determinate state, poised for any action in its repertory; this is the body from the point of view of its potential, or virtuality. Now freeze it as it passes through a threshold state on the way from one determinate state to another. That is a degree of intensity of the body without organs. It is still the body as virtuality, but at a lower level of virtuality, because only the potential states involved in the bifurcation from the preceding state to the next are effectively superposed in the threshold state. The disjunctive synthesis constituted by the bifurcation can still be considered inclusive: although only one alternative is actualized, it includes vibrations from all the other states at different degrees of intensity, and none of those states is excluded a priori from being actualized next. (p. 70)

Drawing on Massumi's interpretation of the $\mathrm{BwO}$, 'becoming' must be considered directional, in that it is in a constant state of movement and transformation, without a predefined telos and therefore open to the actualization of any one of an infinite number of 'becomings-other'. The 'readiness' of the $\mathrm{BwO}$ is therefore concerned with the conditions necessary for that body to destratify, to actualize a particular state of its potential or virtuality. 'Readiness' is actualized as the BwO selects and pursues lines of flight, in the process fundamentally changing its own nature and the nature of multiplicities to which it is connected.

Positively, this destratified movement and the opening up of space in which lines of 'becoming' extend, is an affirmation of complexity and potential. There is, however, need for caution. There is a danger within this open and dynamic space that bodies destratify to the point at which they lose any form of relative consistency, that by challenging domainant striating and organizing structures, classroom spaces dissolve into chaos. As Protevi (2000) identifies, the strata of the organism must be partially maintained in order that the $\mathrm{BwO}$ remain a body. 'Becoming', however, does not inevitably result in the complete dissolution of order. Even within open and dynamic spaces of learning, there can be a certain form of emergent order. As Dewey (1899/2010) states,

...there is a certain disorder in any busy workshop...there is the confusion, the bustle that results from activity. But out of occupation, out of doing things, that are to produce results, and out of doing these in a social and cooperative way, there is born a discipline of its own kind and type. (p. 10)

Within open educational systems and spaces there is an inherent element of responsibility for the growth and development of others and as such it is 'fatal' to "permit capricious or discontinuous action in the name of spontaneous self-expression" (Dewey, 1916, p. 119). There must be order within any system in order for that system to function productively, however, that order must emerge from and be consistent in the "progressive completing of a process" (ibid). In Deleuzian terms, that order must be immanent in the context from which it emerges.

In relation to 'becoming' a $\mathrm{BwO}$ therefore, it cannot be assumed that dynamic and supple movement, in open-space, should be privileged de facto. Deleuze and Guattari 
(1987) make this point very clear, emphasizing the need for caution when breaking away from the striations of state structures. The exercise of caution needs to be a fundamental principle within this reconceptualization of 'readiness'. It is vital that 'open-endedbecoming', in relation to which 'readiness' emerges, is not confused with a romantic notion of development or a laissez-faire attitude that assumes children will develop and progress naturally towards the 'good'. Such an attitude would either reintroduce the transcendent, elevating a particular notion of the 'good life' and the 'innocent child', or create a situation in which all lines of development are considered viable, regardless of their effects.

\section{The ethics of 'becoming'}

Protevi (2000) identifies that whilst the 'plane of consistency' is constituted as an immanent arrangement of $\mathrm{BwO}^{\prime}$ s, not all $\mathrm{BwO}^{\prime}$ 's qualify for inclusion. There has to be a process of selection, making the construction of this plane an ethical endeavor. Protevi (2000; 2001) outlines three distinct types of BwO: full, empty and cancerous - identifying that only the full $\mathrm{BwO}$ is productive, being reached through a process of careful experimental destratification. The full $\mathrm{BwO}$ is not completely destratified, but retains a co-ordination of organs, arranged and negotiated in relation to immanent flows.

Caution and care is therefore vital when constructing the $\mathrm{BwO}$ as too sudden destratification leads only to an empty $\mathrm{BwO}$, devoid of energy flows (Protevi, 2000). Deleuze and Guattari (1987) evoke "a dreary parade of sucked-dry, catatonicized, vitrified, sewn-up bodies...Emptied bodies instead of full ones" (p. 150). They ask, "What happened? Were you cautious enough?" (ibid), identifying caution as a rule immanent to experimentation and destratification. Whilst the full $\mathrm{BwO}$ is always a communal project, created through the continual production of connections, for the empty $\mathrm{BwO}$ there are no energy flows through which to connect. There is no production possible from the empty $\mathrm{BwO}$ and the plane of consistency runs the risk of descending into nihilism. Situating this discussion in the context of early childhood education, there is a particularly useful connection to be made with Dewey's (1916) notion of 'dependence'. Dewey considers dependence to be something positive and constructive in the growth of the young child. Dependence denotes a social (or material) connection, which Dewey defines as interdependence, and in this sense it could be considered a factor in the growth of the full $\mathrm{BwO}$. Through dependence, the $\mathrm{BwO}$ may connect with other BwO's and through that relational activity growth and open-ended development may be promoted. In contrast, the empty BwO may be likened to what Dewey (1916) defines as helplessness. The impotent or helpless body would be devoid of affective connections, existing either in static isolation or as part of a system in which it lacks agency and affective capacity. Dewey elaborates on the passive and static nature of helplessness, stating,

A merely impotent being has to be carried, forever, by others. The fact that dependence is accompanied by growth in ability, not by an ever-increasing lapse into parasitism, suggests that it is something constructive. Being merely sheltered by others would not promote growth. (p.50-51). 
The empty $\mathrm{BwO}$ can be understood as helpless, unable to make connections and to profligate within its milieu. Whilst it may be effectively carried along a line of learning and development, organized according to an ideal standard or static end, this empty $\mathrm{BwO}$ will not be considered 'ready' to take new and unpredictable lines of flight until it breaks with the dominant organizational structure holding it in place, which Deleuze and Guattari (1987) may describe as its 'becoming-minoritarian'.

The third type of BwO identified by Protevi (2000) is the cancerous form. In contrast to the empty $\mathrm{BwO}$, this cancerous form comes about under conditions of runaway stratification and sedimentation resulting in the endless repetition of homogenized subjectivity through a process of conformity and social cloning (Provtevi, 2000). The construction of a 'plane of composition' therefore calls for extreme caution. If too much stratification can lead to a cancer of the stratum, and too sudden destratification can empty the $\mathrm{BwO}$ of its intensities, it is essential that we engage in cautious experimentation, approaching the production of the $\mathrm{BwO}$ and the 'plane of consistency' as a form of ethical selection for the organization of bodies. Conditions of 'readiness' must enable the production of the full $\mathrm{BwO}$, allowing for experimentation with unplanned and unpredictable situations, whilst at the same time, retaining the element of organization that allows the body to be productive in its creativity. The processes, or lines of flight, through which bodies destratify must therefore be selected carefully and conditions of 'readiness' must support the selection of lines that produce positive and affirmative affects.

This notion of ethical selection could be considered problematic in relation to the immanent philosophy underpinning the concepts developed in this paper. It would be a mistake, however, to assume that because an immanent ontology rejects transcendent norms, it has no concept of hierarchy. Jun (2011) suggests that for Deleuze, certain political institutions were indeed to be recommended, whilst others were to be rejected. To illustrate this point, Jun draws a comparison between events in Nazi Germany between 1933 and 1945, and the actions of the freedom fighters battle against apartheid in South Africa. He states,

Most people would regard the actions of the Nazis as morally reprehensible and the actions of the freedom fighters as morally praiseworthy. Although both used violence in the pursuit of political ends, only the latter were allegedly morally justified in doing so. (Jun, 2011, p. 89)

This point is particularly important in reconceptualizing 'readiness' as an active and responsive ethical relationship. Given Deleuze and Guattari's apparent rejection of transcendent norms, such as morality and justice, on what basis is it possible to condemn certain lines of flight and the affects produced from them as bad and destructive, whilst accepting others as good and productive? On what grounds can certain movements and lines of flight be considered 'becomings' (produced by and from which, conditions of 'readiness' can emerge) and others condemned as "morally odious 'alternative practices'” (Jun, 2011, p. 100)?

From a top-down position of transcendent morality, the problem posed by Jun can be considered a question of political normativity, an identification of moral criteria by 
which the actions, policies and existence of political entities can be judged (Jun, 2011). Certain actions, people, institutions etc., are considered bad in relation to particular laws, principles and norms that dictate how we, as human beings, ought to act. Jun (2011) identifies that principally, morality is concerned with an expression of what is right, what ought to be done and the imperatives, obligations and duties that arise from transcendent principles. From an immanent ontological position however, how, without recourse to transcendent norms as parameters for a good and moral life, do we avoid slipping into nihilism and nothingness, a situation where any and all lines of flight are allowed to profligate, opening up to the potential of destruction and despair? Do we run the risk that without normative universals against which to judge behavior, we fall into a chaos of pure subjectivism or relativism (Smith, 2007)? How do we ensure that we are 'ready' to select lines of flight that are productive and life affirming in order to actualise 'ethically-responsive-becomings', as opposed to following lines of flight that are regressive and destructive, for ourselves and for others within the multiplicities to which we are connected?

\section{Interlude: "The relational nature of 'readiness"}

The children were playing in their reception class. A group of 4 girls had gathered around a table containing a selection of collage items. As the girls created their collages, they chatted about what they were doing, sharing their creations and commenting on each other's ideas. The social dynamic of the small group appeared to be deliberately exclusionary of one of the girls (Sarah'). When sharing her picture, the other girls responded with comments such as 'That's horrible", and when she suggested the group could begin a game of 'princesses', they stated, "We're not playing that now, you can play that in nursery", implying this was an activity for younger children and something they had now outgrown. The children's body language also expressed this exclusionary manner, the three girls turning their bodies and faces away form the fourth girl as they sat at the table, and whispering to each other so she couldn't hear their conversations. Whilst the three girls appeared to draw strength in their relationship from this exclusion, this was at the expense of the fourth. Towards the end of the activity, this exclusionary behavior began to question the very visibility of the fourth children's actions at all, as displayed in the following interaction between Sarah and one of the other girls (Rachel), in which Sarah is attempting to share the technique she has been using to create her collage:

Sarah: "Please, watch it, watch it. Just quick, watch it, quick, quick, quick".

Rachel: "I didn't watch it"

Sarah: "Did you see it though"

Rachel: "No"

Sarah: "In the corner of your eye did you see it?"

Rachel: "mmmmmm ... no ... I didn't see that either"

The episode ended with the three girls taking their collages to hang on the walls of the play house, informing Sarah that she couldn't come with them because only three could play in there.

${ }^{6}$ Pseudonyms used for all names 
This example helped me to think about the relational nature of children's 'readiness' in the context of their day-to-day educational experience. Whilst the three girls actions progressed their own interests, this was at the expense of Sarah's positive becoming, as their actions actively suppressed her ability to become within the context of the activity. This observation prompted the idea that children's 'readiness' for positive progression in their learning and development must take account of the positive progression of others and the 'readiness' of others to engage in productive 'becomings'.

If 'readiness' is to be conceptualized in relation to the conditions necessary for 'becoming' to emerge, it is essential that this conceptualization have an ethical dimension. The 'becomings' that emerge from these conditions of 'readiness' must be active and productive, as 'readiness', conceptualized in this way, can only open out to positive progression. The activity of the child within their milieu must "tend toward valuable results" (Dewey, 1899/2010, p. 17) through direction and organization that emerge as immanent to the process of learning and development. Conditions of 'readiness' emergent within the milieu or multiplicity must allow for dynamic and productive activity, enabling what Dewey (1899/2010) describes as "go, movement, the sense of use and operation" (p. 52). Crucially therefore, what emerges from conditions of 'readiness' must be active, productive and affirmative for the child and the multiplicity within which they are connected. If what emerges from these conditions of 'readiness' is destructive, passive and negative, it could be argued that they were never conditions of 'readiness' in the first place.

\section{Becoming, hierarchy and responsibility}

As an 'active-ethical-relation', conditions of 'readiness' and 'lines-of-becoming' can be understood in terms of forces composing different bodies and their relations. Deleuze (1983) states, "In a body the superior or dominant forces are known as active and the inferior or dominated forces are known as reactive" (p. 40). He considers active and reactive to be the qualities that express relation of force with force. He identifies;

forces which enter into relation do not have quantity without each of them having, at the same time, the quality corresponding to their difference in quantity as such. This difference between forces qualified according to their quantity as active or reactive will be called hierarchy. (1983, p. 40)

The existence of this hierarchical relationship between forces creates an immanent rationale for the selection of some lines of flight as positive 'becomings' and the exclusion of others as dangerous. For Deleuze, following Nietzsche, reactive forces are inferior in terms of their quality as they seek to secure and maximize quantity through mechanical means and final ends. He states, "This is the point of departure for reaction: The mechanical and utilitarian accommodations, the regulations which express all the power of inferior and dominated forces" (1983, pp. 40-41). Reactive forces are concerned with the denial of difference as mechanistic ideas impose a final end or terminal state on 'becoming' that constructs a binary of 'being'/'nothing'. Either the terminal state (of 'readiness' for the next stage) is achieved, or the line of flight descends into nothingness. 
Deleuze claims, "The instrument of nihilistic thought is the triumph of reactive forces" (1983, p. 45). A reactive force triumphs by separating an active force from what it can do, taking away all or part of its power. Deleuze (1983) considers that the victory of reactive force does not proceed by addition; rather, this victory happens via a subtraction that denies active forces their difference and separates them from what they can do.

For Deleuze (1983) active and reactive forces are characterized in a number of ways. Reactive forces are utilitarian forces of adaption and imitation, they are separated from what they can do and as a result deny their difference and turn against themselves. In contrast, active forces are those that go to the limit of what they can do, making difference an object of affirmation. This affirmation of difference is a crucial component of 'becoming-active'. In order to 'become-active' forces must affirm difference, both in themselves and in others. Deleuze states, "in order to become active it is not sufficient for a force to go to the limit of what it can do, it must make what it can do an object of affirmation" (1983, p.68). 'Becomings' must therefore be life affirming and in the context of the multiplicity, this introduces an element of responsibility for the other.

\section{Interlude 5: 'Let's be space builders!'}

I observed a young boy playing in the space of the early childhood classroom. There were groups of children engaged in activities led by adults, and children playing independently across different areas of the classroom environment. As I observed this young boy he rushed busily around the space, never lingering for too long in one place, moving quickly, with purpose, but without much apparent concern for the activities of those around him. He held a space rocket in one hand as he moved, making it fly along side him as he ran. As he rushed past a table on which children were building with blocks, his trailing arms knocked over their constructions. He ran on apparently oblivious to the upset he had caused, running around tables and through a train track that was being built on the floor. The shouts and protestations of the children who had been building brought him to a stop. He turned around, appearing concerned about the upset he had caused. When he realized his actions had caused other children distress and disrupted their play, he punched his fist in the air and shouted, "let's be builders, fix it, fix it!" He began to load blocks, a few at a time, into his space rocket, flying them back to the table and saying to the children there, "Let's build it again, let's be space builders!" I was struck by the way in which this boy was able to redirect his play in response to the affect his initial actions had on others. He showed both an awareness of his actions in relation to others, to whom he was connected, and a 'readiness' to redirect his own lines of flight in response to this relation and its affects.

Cunniff Gilson (2011) recognises 'becoming' as a process through which we are called to be responsive to others. She states,

As a question of becoming, responsibility both involves and demands a certain mode of relationship and engagement with others, and not simply with them as molar entities but with that which composes them. One is responsible because one is in the midst of, linked to, and becoming through something with the other. (pp. 79-80)

'Becoming' involves not only individual bodies 'going to the limit of what they can do', but through their relationships with other bodies, the generation of positive affects 
within the multiplicity. The augmentation of one body cannot be at the expense of another, hindering the others 'active-becomings', denying their difference or appropriating the power of their relative forces. To be responsible within a process of 'becoming' is therefore "to refrain from connecting one's body with other bodies in ways that decompose the relations that constitute them or diminish their powers, and instead to find compositions with others that enhance the powers of both" (Cunniff Gilson, 2011, p. 80).

As an ethical relationship this responsive 'becoming' is not a simple matter of selecting actions that correspond to normative ideas of how we should act in relation to the pursuit of a 'good' life. It is an oversimplification to think that we can identify certain actions as 'good', contributing to positive affirmation and transformation, and others as bad, leading to negation and destruction. On a 'plane of composition', the affects of ethical relations must be understood as situational, as a response to actual conditions. Whether a certain action affects a 'becoming' of active force, or a triumph of reaction, is then dependent on the context in which that action occurs. As identified by Spinoza (1677/2001), "no action considered in itself alone is either good or evil" (pp. 206-207). Deleuze (1988b) draws on Spinozian ethics stating, "what matters is knowing whether the act is associated with the image of the thing insofar as that thing can compound with it, or, on the contrary, insofar as it is decomposed by it" (pp. 35-36, emphasis original).

The nature of a line of flight cannot, therefore, be judged in relation to higher order principles of good/bad, right/wrong. Its nature is emergent from the context in which it arises, from the relations and connections it forms and the affects produced through those relations. The ethics of the line of flight are therefore completely immanent, arising from the situation as concrete and specific. This ethically responsive space is experienced "in terms of pure relations of movements rather than a retrospective construct of a socially shared space" (Lorraine, 2005, p. 173). Considering 'readiness' as an 'activeethical-relation' therefore demands attention not only to our own 'becoming-other', but also to the 'becoming-of-others' and the affects produced from the conditions of 'readiness' that emerge when our lines of flight cross.

\section{Conclusion}

Within a multiplicity, 'readiness' cannot be understood in terms of separate and discrete entities, of one part being made 'ready' for another part, but must be considered as an affective production emergent from the connections of multiple lines of flight. In this sense, 'readiness' becomes a highly complex concept. Reconceptualized as the conditions that allow for 'open-ended-becoming-active', readiness becomes a co-ordination of haecceities. The denial of the line of flight of an-other, in favor of one's own progression would be to deny 'readiness' within the assemblage of forces that make up the multiplicity. To become-active is not to progress at the expense of an-other but to pursue lines of flight that "lead to the proliferation of enlivening connections" (Lorraine, 2005, p. 163). 'Readiness', therefore, can be understood as a complex arrangement of elements within a qualitative multiplicity that, through a process of 'strong emergence', creates 
conditions for the 'becoming' of an "open-ended humanity that we can unfold together" (Lorraine, 2005, p. 174). It is complex and requires the kind of cautious experimentation advocated by both Deleuze (and Guattari) and Dewey, deterritorializing educational multiplicities to the extent that we open up the field for unpredictable, dynamic and creative 'becomings', but not so much that we lose any form of consistency immanent to the multiplicity itself. 'Readiness' can be understood, therefore, as the conditions necessary to allow a departure from predetermined norms, deterritorializing and transforming dominant patterns of learning and development through the following of positive and productive lines of flight. Understood in this way, 'readiness' becomes both an ethical and a political concept, the pursuit of which is essential in the development of an open and inclusive landscape of early childhood education, that through experiments in living, despite the risks they entail, helps us to evolve creatively with the 'becoming-other' of life (Lorraine, 2005).

\section{References}

Baugh, B. (2010). Body. In A. Parr (Ed.), The Deleuze dictionary (pp. 35-37). Edinburgh: Edinburgh University Press.

Biesta, G. (2010). Five theses on complexity reduction and its politics. In, D. Osberg, \& G. Biesta (Eds). Complexity theory and the politics of education (pp. 5-13). Rotterdam: Sense Publishers.

Cunniff Gilson, E. (2011). Responsive becoming: Ethics between Deleuze and feminism. In N. Jun \& D. W. Smith (Eds). Deleuze and ethics. (pp. 63-88). Edinburgh: Edinburgh University Press.

Deleuze, G. (1983). Nietzsche and philosophy. London: The Athlone Press.

Deleuze, G. (1988a). Bergsonism, New York: Zone Books.

Deleuze, G. (1988b). Spinoza: Practical philosophy, San Francisco: City Lights Books.

Deleuze, G. \& Guattari, F. (1987). A thousand plateaus: Capitalism and schizophrenia. Minneapolis: University of Minnesota Press.

Dewey, J. (1899/2010). The school and society and the child and curriculum. digireads.com.

Dewey, J, (1916). Democracy and education: An introduction to the philosophy of education. New York: The Macmillan Company.

Department for Education (DfE). (2012). Statutory framework for the early years foundation stage. Available at: https://www.education.gov.uk/publications/standard/AllPublications/Page1/DFE-00023-2012.

Department for Education (DfE). (2013). Early years outcomes. Available at:.

Evans, K. (2013). "School Readiness": The Struggle for Complexity. LEARNing Landscapes, 7(1), 171186.

Jun, N. (2011). Deleuze, Values and Normativity. In N. Jun \& D. W. Smith (Eds). Deleuze and ethics (pp. 89-107). Edinburgh,: Edinburgh University Press.

Lorraine, T. (2005). Ahab and Becoming-Whale: The Nomadic Subject in Smooth Space. In I. Buchanan \& G. Lambert (Eds.). Deleuze and space (pp. 159-175). Edinburgh: Edinburgh University Press.

Lorraine, T. (2010). Lines of Flight. In A. Parr (Ed). The Deleuze dictionary. Edinburgh: Edinburgh University Press.

MacNaughton, G. (2005). Doing Foucault in early childhood studies: Applying poststructural ideas. Oxon: Routledge.

Massumi, B. (1992). A user's guide to Capitalism and schizophrenia: Deviations from Deleuze and Guattari. Cambridge, MA: Massachusetts Institute of Technology.

Osberg, D., \& Biesta, G. (2010). Complexity, education and politics from the inside-out and the outside-in. In, D. Osberg, \& G. Biesta (Eds). Complexity theory and the politics of education ( pp. 1-3). Rotterdam: Sense Publishers, 
Parr, A. (2010). Creative Transformation. In A. Parr (Ed). The Deleuze dictionary (pp. 59-61). Edinburgh: Edinburgh University Press,.

Protevi, J. (2000). A Problem of Pure Matter: Fascist Nihilism in A Thousand Plateaus. In K. AnsellPearson, \& D. Morgan (Eds). Nihilism now! Monsters of energy (pp. 167-188). London: St Martin's Press

Protevi, J. (2001). The organism as the judgment of god: Aristotle, Kant and Deleuze on nature (that is, on biology, Theology and politics). In M. Bryden (ed). Deleuze and Religion (pp. 30-41). London: Routledge.

Semetsky, I. (2003). Deleuze's new image of thought, or Dewey revisited. Educational Philosophy and Theory, 35(1), 17-29.

Semetsky, I. (2006). Deleuze, education and becoming. Rotterdam: Sense Publishers.

Semetsky, I. (2011). Becoming-Other: developing the ethics of integration. Policy Futures in Education, 9(1), 138-144.

Smith, D. W. (2007). Deleuze and the question of desire: Toward an immanent theory of ethics. PARRHESIA, 9, 66-78.

Spinoza, B. (1677/2001). Ethics. Ware: Wordsworth Editions Limited.

Stagoll, C. (2010). Becoming. In A. Parr (Ed). The Deleuze dictionary (pp. 25-27). Edinburgh: Edinburgh University Press.

Zukauskaite, A. (2011). Ethics between Particularity and Universality. In N. Jun \& D. W. Smith (Eds). Deleuze and ethics (pp. 188-206). Edinburgh: Edinburgh University Press.

\section{Acknowledgments}

The author would like to thank the Economic and Social Research Council, England, for their funding of the doctoral work from which this paper has emerged. Thanks also to the communities of educators and children who have inspired the thinking presented in this paper, their generosity in collaboration has made this research possible.

\section{About the Author}

Katherine Evans is a doctoral student at the University of Exeter, in the United Kingdom. Prior to embarking on her doctoral studies, she was an early years teacher, working in nursery settings, primary schools and children centers. Her doctoral work explores the concept of 'readiness' in the context of early childhood education. Katherine can be contacted at khle201@exeter.ac.uk.

(c) Copyright 2015. The authors, KATHERINE EVANS, assigns to the University of Alberta and other educational and non-profit institutions a non-exclusive license to use this document for personal use and in courses of instruction provided that the article is used in full and this copyright statement is reproduced. The author also grants a non-exclusive license to the University of Alberta to publish this document in full on the World Wide Web, and for the document to be published on mirrors on the World Wide Web. Any other usage is prohibited without the express permission of the authors. 